Journal of Economic, Business and Accounting (COSTING)

Volume 1 Nomor 2, Juni 2018

e-ISSN : 2597-5234

https://doi.org/10.31539/costing.v1i2.263

IDMEKpe

\title{
PENGARUH SERVICE MARKETING MIX TERHADAP KEPUTUSAN NASABAH UNTUK MENABUNG PADA PT. BANK MAYAPADA INTERNASIONAL TBK CABANG A.YANI PEKANBARU
}

\section{THE EFFECT OF SERVICE MARKETING MIX TOWARD CUSTOMER'S SAVING DECISION IN PT. BANK MAYAPADA INTERNATIONAL TBK BRANCH A.YANI PEKANBARU}

\author{
Evelyn Wijaya, Puspa Marantika Ariyanti \\ Sekolah Tinggi Ilmu Ekonomi Pelita Indonesia Pekanbaru ${ }^{1,2}$ \\ evelynwijaya53@gmail.com ${ }^{1,2}$
}

\begin{abstract}
Right now the amount of bank in Indonesia has reached 115 bank (OJK). Increasing number of bank has impact to increasing level of competition. Marketing becomes one of important activity in the company to keep the company existency to develop and get a profit. This research aims to test the influence of service marketing mix (product, price, place, promotion, process, people and physical evidence) on customer saving decision at PT Bank Mayapada International Tbk Cabang A.Yani Pekanbaru. The sample used are 100 respodents by using accidental sampling method. The data analyzed using multiple linear regression. The result showed that product, place, process and person has a significant effect on customer saving decision whereas price, promotion and physical evidence has no significant effect to customer saving decision at PT Bank Mayapada International Tbk Cabang A.Yani Pekanbaru.
\end{abstract}

Keywords: Product, Price, Place, Promotion, Process, Person, Physical Evidence and Customer Saving Decision.

\begin{abstract}
ABSTRAK
Saat ini jumlah perbankan di Indonesia telah mencapai 115 bank (OJK). Peningkatan jumlah perbankan akan berdampak pada peningkatan tingkat persaingan. Pemasaran menjadi salah satu aktivitas utama bagi perusahaan untuk menjaga eksistensi perusahaan untuk berkembang dan mendapatkan laba. Penelitian ini bertujuan untuk mengetahui pengaruh bauran pemasaran jasa (produk, harga, lokasi, promosi, proses, orang dan bukti fisik) terhadap keputusan nasabah untuk menabung pada PT Bank Mayapada International Tbk Cabang A.Yani Pekanbaru. Penelitian ini menggunakan sampel sebanyak 100 responden dengan menggunakan teknik accindental sampling. Teknik analisa data menggunakan analisa regresi linear berganda. Hasil penelitian memperlihatkan bahwa produk, tempat, proses dan orang berpengaruh signifikan terhadap keputusan nasabah untuk menabung sedangkan harga, promosi dan bukti fisik tidak berpengaruh signifikan terhadap keputusan nasabah untuk menabung pada PT Bank Mayapada International Tbk Cabang A.Yani Pekanbaru.
\end{abstract}

Kata Kunci: Produk, Harga, Lokasi, Promosi, Proses, Orang, Bukti Fisik, Keputusan Nasabah untuk Menabung 


\section{PENDAHULUAN}

Kondisi perbankan Indonesia dewasa ini semakin menunjukkan tingkat persaingan yang ketat baik untuk lembaga keuangan bank maupun non bank. Berdasarkan laporan yang termuat dalam Statistik Perbankan Indonesia (SPI) menyatakan bahwa hingga bulan Agustus 2017, jumlah kantor bank umum tercatat sebanyak 32.635 unit, jumlah bank tercatat sebanyak 115 unit, Jumlah BPR tercatat sebanyak 1.618 bank (www.ojk.go.id).

Dengan semakin banyaknya lembaga keuangan yang menjalankan kegiatan dalam hal pembiayaan ini mendorong setiap perbankan untuk memberikan kualitas pelayanan yang terbaik. Selain kualitas pelayanan, kegiatan pemasaran juga merupakan kegiatan utama perbankan dalam upaya untuk menjaga, memelihara dan mempertahankan eksistensinya di mata nasabah. Dalam kegiatan pemasaran, bank harus mampu menarik minat dan kepercayaan calon nasabah untuk menggunakan produk atau jasa yang ditawarkan oleh bank tersebut atau setidaknya calon nasabah berkeinginan untuk menyimpan dananya di bank.

Setiap perbankan bersaing untuk mendapatkan nasabah yang diwujudkan melalui pengembangan produk perbankan (tabungan, giro dan deposito), menyediakan fasilitas penarikan dana (ATM) yang dapat diakses oleh nasabah dimanapun dan kapanpun, menyediakan fasilitas mobile banking yang dapat semakin mempermudah proses transaksi yang dilakukan oleh nasabah sehingga nasabah akan merasa puas dengan fasilitas yang ditawarkan oleh bank tersebut.

Agar nasabah merasa puas dengan segala sesuatu yang ditawarkan oleh perbankan, pihak perbankan memberikan rangsangan berupa balas jasa dalam bentuk bunga, bagi hasil, hadiah, pelayanan, atau balas jasa lainnya. Semakin tinggi balas jasa yang diberikan maka akan menambah minat nasabah untuk menyimpan dananya di bank tersebut. Oleh karena itu, pihak perbankan harus memberikan berbagai rangsangan dan kepercayaan sehingga nasabah tertarik untuk menanamkan dananya.

Salah satu perbankan yang menjadi objek dalam penelitian ini adalah Bank Mayapada Internasional Cabang A.Yani Pekanbaru. Dari hasil survei awal yang dilakukan terhadap beberapa nasabah Bank Mayapada ditemukan bahwa strategi pemasaran yang dilakukan oleh bank belum berjalan maksimal. Hal ini dibuktikan dengan adanya penurunan jumlah nasabah yang menyimpan dananya di Bank Mayapada dari tahun ke tahun.

Tabel 1. Nasabah Bank Mayapada Cabang A.Yani Pekanbaru Tahun 20142016

\begin{tabular}{lll}
\hline Tahun & $\begin{array}{l}\text { Jumlah } \\
\text { Nasabah }\end{array}$ & Persentase \\
\hline 2014 & 608 & - \\
\hline 2015 & 549 & $(10.75 \%)$ \\
\hline 2016 & 538 & $(20.04 \%)$ \\
\hline
\end{tabular}

Sumber: Bank Mayapada Cabang A.Yani Pekanbaru 2017

Berdasarkan tabel 1 diatas, terlihat adanya penurunan jumlah nasabah dari tahun 2014 sampai dengan 2016. Saat ini jumlah nasabah Bank Mayapada Cabang A.Yani Pekanbaru sebanyak 538 nasabah dengan persentase penurunan sebesar $20.04 \%$.

Strategi pemasaran dapat terpenuhi dengan penyediaan suatu sarana yang disebut bauran pemasaran (marketing mix). bauran pemasaran (marketing mix) merupakan perangkat pemasaran yang baik yang meliputi produk, penentuan harga, promosi dan distribusi yang digabungkan untuk menghasilkan respon yang diinginkan oleh pasar sasaran (Kotler dan Amstrong, 2012). Hal tersebut penting karena bauran pemasaran merupakan salah satu pokok 
pertimbangan nasabah dalam melakukan keputusan menabung. Jika bank tidak peka terhadap apa yang dibutuhkan nasabah, maka dapat dipastikan bahwa bank akan kehilangan banyak kesempatan untuk menjaring nasabah dan produk yang ditawarkan akan sia-sia.

Lovelock dan Wirtz (2011) menyatakan bahwa teori bauran pemasaran mengalami perkembangan dimana untuk industri jasa dilakukan penambahan 3P sehingga menjadi 7P yaitu proses (process), orang (people), dan bukti fisik (physical evidence). Pengembangan bauran pemasaran jasa ini dapat mempermudah bank ataupun perusahaan jasa lainnya untuk menetapkan strategi pemasaran yang tepat.

Berdasarkan hasil survei awal yang dilakukan terhadap 25 nasabah bank dijumpai beberapa permasalahan terkait dengan produk yaitu (1) sebagian nasabah juga menjadi nasabah dari dua atau lebih bank yang dikarenakan adanya kebutuhan produk atau jasa yang tidak dapat terpenuhi dari salah satu bank, (2) produk perbankan yang ditawarkan masih terbatas, (3) mesin ATM yang disediakan belum memiliki fitur transaksi keuangan yang lengkap. Produk merupakan bagian yang penting sebagai upaya untuk mempertahankan dan menarik nasabah bank.

Selain produk, penurunan jumlah nasabah pada Bank Mayapada Internasional juga disebabkan oleh komponen harga dimana bank membebankan nilai biaya administrasi yang cukup tinggi kepada nasabah dibandingkan dengan bank-bank lainnya yang setara. Lokasi pun menjadi pertimbangan nasabah dimana lokasi tempat parkir kendaraan yang sempit mempersulit nasabah bank pada saat melakukan transaksi. Promosi menjadi komponen bauran pemasaran yang berikutnya dimana permasalahan yang dijumpai yakni ketersediaan brosur di banking hall yang tidak update, undian berhadiah yang ditawarkan kurang menarik bagi nasabah.

Proses menjadi bagian yang penting dalam perusahaan jasa. Nasabah menginginkan proses transaksi yang tidak memakan waktu yang lama serta penyelesaian keluhan yang tanggap dari karyawan. Permasalahan yang dijumpai saat ini yakni proses penyelesaian keluhan nasabah membutuhkan waktu lebih kurang 14 hari kerja (masalah pendebitan dana) sehingga membuat nasabah harus menunggu lebih lama. Hal ini juga menjadi penyebab penurunan jumlah nasabah bank.

Karyawan merupakan asset bagi perusahaan untuk dapat menjalankan aktivitasnya dengan baik. Untuk menghasilkan karyawan yang terampil dibidangnya diperlukan pelatihan-pelatihan yang diadakan oleh perusahaan. Hal ini dapat meningkatkan kepuasan konsumen pkaryawan belum mampu memberikan service excellent yang baik kepada nasabah.

Bukti fisik juga menjadi faktor penyebab terjadinya penurunan jumlah nasabah dimana hal ini disebabkan karena penjagaan satpam yang kurang disiplin serta ketidaknyamanan pada saat melakukan transaksi sehingga pada akhirnya nasabah tidak akan percaya untuk menyimpan dananya di bank tersebut dan akan beralih pada perbankan lain yang lebih terpercaya.

Penelitian yang dilakukan oleh Zainul Arifin (2013) menyatakan bahwa komponen harga, promosi, orang, bukti fisik, dan lokasi tidak berpengaruh signifikan terhadap keputusan menabung sedangkan komponen produk dan proses berpengaruh positif signifikan terhadap keputusan menabung pada Bank Muamalat Malang. Sedangkan penelitian yang dilakukan oleh Reni Gusnawati (2014), menyatakan bahwa komponen produk, lokasi, orang, bukti fisik berpengaruh positif signifikan terhadap keputusan nasabah menabung sedangkan komponen harga, 
promosi dan proses tidak berpengaruh signifikan terhadap keputusan nasabah menabung di BRI. Penelitian ini sejalan dengan penelitian yang dilakukan oleh Devi Kumala Sari (2015) yang menyatakan bahwa produk, promosi dan proses berpengaruh terhadap keputusan nasabah menabung sedangkan harga, orang, tempat dan bukti fisik tidak berpengaruh terhadap keputusan nasabah menabung.

Tujuan daripada penelitian ini adalah untuk menganalisa bauran pemasaran jasa (7P) secara parsial terhadap keputusan nasabah untuk menabung pada Bank Mayapada International Cabang A.Yani Pekanbaru. Sedangkan manfaat daripada penelitian ini adalah untuk memberikan informasi kepada pihak manajemen bank dalam penetapan strategi pemasaran yang tepat untuk meningkatkan kinerja perbankan. sedangkan bagi nasabah dapat dijadikan pertimbangan dalam pengambilan keputusan menabung di Bank Mayapada International Cabang A. Yani Pekanbaru.

Fandy Tjiptono (2011), bauran pemasaran jasa merupakan seperangkat alat yang dapat digunakan pemasar untuk membentuk karakteristik jasa yang ditawarkan kepada pelanggan. Bauran pemasaran jasa merupakan kombinasi dari konsep bauran pemasaran produk yaitu produk, harga, promosi dan lokasi (Sumarmi dan Soeprihanto,2010). Pemasaran saat ini bukan hanya sekedar menjual dengan dimensi jangka pendek tetapi memasarkan dengan dimensi jangka panjang.

Bagi dunia perbankan yang menjadi badan usaha yang berorientasi profit, kegiatan pemasaran sudah merupakan suatu kebutuhan utama dan suatu keharusan untuk dijalankan. Tanpa kegiatan pemasaran maka kebutuhan dan keinginan pelanggan tidak akan terpenuhi. Oleh karena itu, bagi dunia usaha khususnya perbankan perlu menciptakan kegiatan pemasarannya secara terpadu dan terus-menerus melalui suatu riset pemasaran. Pemasaran bank merupakan suatu proses untuk menciptakan dan mempertukarkan produk atas jasa bank yang ditujukan untuk memenuhi kebutuhan dan keinginan nasabah dengan cara memberikan kepuasan.

Dalam pemasaran terdapat strategi pemasaran yang disebut bauran pemasaran (marketing mix) yang memiliki peranan penting dalam mempengaruhi konsumen agar dapat membeli suatu produk atau jasa yang ditawarkan oleh perusahaan. Elemenelemen bauran pemasaran terdiri dari semua variabel yang dapat dikontrol perusahaan untuk memuaskan para konsumen. Bauran pemasaran terdiri dari 4 (empat) komponen dalam strategi pemasaran yang disebut 4P, yaitu :

1. Produk adalah suatu barang, jasa, atau gagasan yang dirancang dan ditawarkan oleh perusahaan untuk memenuhi kebutuhan konsumen.

2. Harga adalah jumlah uang yang harus dibayar oleh konsumen untuk mendapatkan produk

3. Lokasi adalah penempatan suatu produk agar tersedia bagi target konsumen, sejenis aktivitas yang berkaitan denan bagaimana menyampaikan produk dari produsen ke konsumen.

4. Promosi adalah aktivitas komunikasi dan penyampaian berbagai informasi mengenai produk kepada konsumen, dan membujuk target konsumen untuk membeli produk.

Pada perkembangannya, menurut Lovelock dan Wirtz (2011), teori bauran pemasaran juga disesuaikan dengan kondisi industri dimana industri jasa dilakukan penambahan $3 \mathrm{P}$ sehingga menjadi $7 \mathrm{P}$ yaitu:

1. Proses dimana pelayanan menjadi perhatian, penciptaan dan pemberian elemen produk memerlukan desain dan pelaksanaan proses yang efektif.

2. Bukti fisik yang mencakup desain dari penampilan pelayanan,dari bangunan, 
landscaping, kendaraan, peralatan, seragam staf, dan lainnya yang terlihat memberikan bukti nyata atau kualitas pelayanan perusahaan, fasilitas pelayanan, dan membimbing konsumen melalui proses pelayanan.

3. Orang adalah sekelompok individu yang berinteraksi langsung dengan konsumen yang membutuhkan suatu keterampilan interpersonal yang baik dan sikap positif. Ketujuh unsur bauran pemasaran yang tercipta saling berkaitan satu sama lain sehingga dapat menghasilkan strategi pemasaran yang efektif yang diiginkan oleh pasar sasaran sehingga pada akhirnya dapat menciptakan kepuasan konsumen.

Menurut Kotler dan Amstrong (2012) produk adalah segala sesuatu yang dapat ditawarkan ke pasar untuk mendapat perhatian, dibeli, digunakan, maupun dikonsumsi untuk memuaskan keinginan atau kebutuhan konsumen. Produk adalah pemahaman subjektif dari produsen atas sesuatu yang bisa ditawarkan sebagai usaha untuk mencapai tujuan organisasi melalui pemenuhan kebutuhan dan kegiatan konsumen, sesuai dengan kompetensi dan kapasitas organisasi serta daya beli pasar.

Dalam dunia perbankan, produk yang diinginkan oleh nasabah adalah produk yang mempunyai kualitas baik dan dapat dipercaya serta mampu memberikan manfaat serta kegunaaan. Hal ini penting karena tanpa adanya produk, strategi pemasaran lainnya tidak dapat dilakukan. Oleh karena itu, dengan adanya produk yang bervariasi yang ditawarkan oleh bank, kemudahaan bertransaksi menggunakan mesin atm dan dengan adanya fitur ATM berupa penarikan tunai, transfer, pembelian dan pembayaran maka akan mendorong nasabah untuk mengambil keputusan menabung.

Harga merupakan bauran pemasaran yang bersifat fleksibel dimana suatu harga akan stabil dalam jangka waktu tertentu, akan tetapi dalam seketika harga dapat meningkat atau menurun terhadap pendapatan dari hasil penjualan tersebut. Kotler dan Amstrong (2012) harga adalah sejumlah uang yang ditagih atas suatu produk dan jasa atau jumlah dari nilai yang ditukarkan para pelanggan untuk memperoleh manfaat dari memiliki atau menggunakan suatu produk atau jasa. atau jasa oleh konsumen.

Komponen harga yang dimaksud dalam dunia perbankan adalah biaya administrasinya, suku bunga tabungan, dan saldo minimum. Apabila perbankan dapat memenuhi keinginan nasabah akan biaya administrasi yang rendah, tingkat suku bunga yang bersaing, serta dengan saldo minimum yang rendah maka hal tersebut juga akan mendorong nasabah untuk mengambil keputusan menabung.

Menentukan tempat untuk setiap bisnis merupakan suatu tugas penting bagi pemasar, keputusan yang salah dapat mengakibatkan kegagalan sebelum bisnis dimulai. Menurut Kotler dan Amstrong (2012) menyatakan bahwa lokasi yaitu berbagai kegiatan perusahaan untuk membuat produk yang dihasilkan atau dijual terjangkau dan tersedia bagi pasar sasaran.

Dalam strategi bauran pemasaran, lokasi merupakan faktor yang sangat penting bagi keputusan nasabah. Pertimbangan nasabah dalam mengambil keputusan menabung mencakup lokasi perbankan yang strategis, tempat parkir yang memadai, dan suasana ruangan pada saat transaksi yang nyaman yang akan mendorong nasabah untuk mengambil keputusan menabung.

Promosi adalah kegiatan pemasaran dalam rangka menginformasikan dan mendorong permintaan terhadap produk, jasa, dan ide dari perusahaan dengan cara memengaruhi konsumen agar mau membeli produk dan jasa yang dihasilkan oleh perusahaan(Rangkuti,2010).

Ali (2013) mengemukakan bahwa semakin gencar kegiatan promosi yang 
dilakukan perusahaan maka konsumen akan semakin tertarik dan terpengaruh sehingga akhirnya konsumen akan membeli produk yang dihasilkan dan ditawarkan perusahaan. Keberhasilan dan pelaksanaan program promosi yang tepat akan berdampak positif dalam memperlancar penyebaran suatu produk atau jasa untuk mencapai pangsa pasar yang ditargetkan perusahaan.

Dalam International Journal of Marketing Studies mengemukakan bahwa salah satu keuntungan dari promosi adalah mereka dapat merangsang konsumen untuk berpikir dan mengevaluasi merek dan kemungkinan melakukan pembelian. Oleh karena itu, banyak pemasar dan pengecer memanfaatkan berbagai jenis alat promosi dan strategi dalam rangka untuk memahami preferensi konsumen dan meningkatkan penjualan mereka.

Promosi tidak kalah penting bagi pertimbangan nasabah dalam mengambil keputusan menabung, tanpa promosi yang dijalankan perusahaan maka nasabah tidak akan mengenal produk tersebut. Sehingga dengan ketersediaan brosur, hadiah yang didapat pada saat melakukan pembukaan tabungan, kemampuan personal selling dari marketing bank dalam menjelaskan produk perbankan akan mendorong nasabah untuk mengambil keputusan menabung.

Ratih Hurriyati (2010) menyatakan bahwa proses adalah semua prosedur aktual, mekanisme dan aliran aktivitas yang digunakan untuk menyampaikan jasa. Seluruh aktivitas kerja adalah proses, proses melibatkan prosedur, jadwal, mekanisme, aktivitas, dan rutinitas dengan produk jasa disalurkan kepada pelanggan.

Proses dalam bauran pemasaran merupakan kegiatan yang mempengaruhi produk yang dikerjakan. Dalam dunia perbankan yang dimaksud dengan proses yakni pembukaan rekening tabungan, pengurusan maupun pencairan deposito maupun giro, kecepatan pelayanan keliuhan nasabah. Kegiatan inilah yang dapat mendorong nasabah dalam mengambil keputusan menabung.

Menurut Ratih Hurriyati (2010) menyatakan bahwa orang (people) dalam bauran pemasaran adalah semua pelaku yang memainkan peranan dalam penyajian jasa sehingga dapat mempengaruhi presepsi pembeli. Elemen- elemen dari orang adalah pegawai perusahaan, konsumen, konsumen lain dalam lingkungan jasa. Semua sikap dan tindakan karyawan bahkan cara berpakaian karyawan dan penampilan karyawan mempunyai pengaruh terhadap presepsi konsumen atau keberhasilan penyampaian jasa.

Dalam perbankan para karyawan atau staff dituntut untuk mampu menunjukkan sikap yang baik dan ramah terhadap nasabah. Selain itu, perbankan juga memberikan pelatihan kepada karyawan sehingga karyawan akan semakin terampil dan menambah pengetahuan guna mendukung kinerja karyawan dalam memberikan service excellent kepada nasabah. Oleh karena itu, people merupakan pertimbangan nasabah dalam melakukan keputusan menabung.

Menurut Kotler dan Keller (2016) bukti fisik adalah bukti yang dimiliki oleh penyedia jasa yang ditujukan kepada konsumen sebagai usulan nilai tambah konsumen. Bukti fisik merupakan wujud nyata yang ditawarkan kepada pelanggan ataupun calon pelanggan. Unsur yang termasuk didalam bukti fisik diantara lain lingkungan fisik, dalam hal ini bangunan fisik, peralatan, perlengkapan, logo, warna dan barang- barang lainnya yang disatukan dengan service yang diberikan.

Perbankan harus memperhatikan kenyamanan nasabah ketika akan melakukan transaksi di bank dengan cara memberikan kenyamanan ruang tunggu nasabah yang nyaman dan bersih dengan suhu ruangan yang stabil, tempat parkir yang memadai, 
logo bank yang dapat dilihat dari jarak jauh, dan bukti fisik lainnya. Bukti fisik juga menjadi pertimbangan nasabah dalam mengambil keputusan menabung.

Menurut Kotler dan Armstrong (2012) perilaku keputusan pembelian mengacu pada perilaku pembelian akhir dari konsumen, baik individual, maupun rumah tangga yang membeli barang dan jasa untuk konsumsi pribadi.

Banyaknya bank dengan berbagai kelebihan dan kekurangan masing-masing, membuat konsumen harus selektif dalam memilih bank sebagai tempat untuk melakukan transaksi keuangan. Sikap konsumen yang telah terpola dari proses pengenalan kebutuhan akan merangsang konsumen untuk melakukan pencarian informasi baik secara internal maupun eksternal. Informasi ini akan menggiring konsumen untuk mengambil evaluasi alternatif tentang keputusan pembelian yang dipengaruhi kepercayaan, sikap, dan nilai yang dimiliki calon konsumen yang pada akhirnya akan mengambil sebuah keputusan pembelian/penggunaan atau tidak, termasuk proses pemecahan masalah pasca pembelian/penggunaan. Kerangka pemikiran yang digunakan dalam penelitian ini adalah:

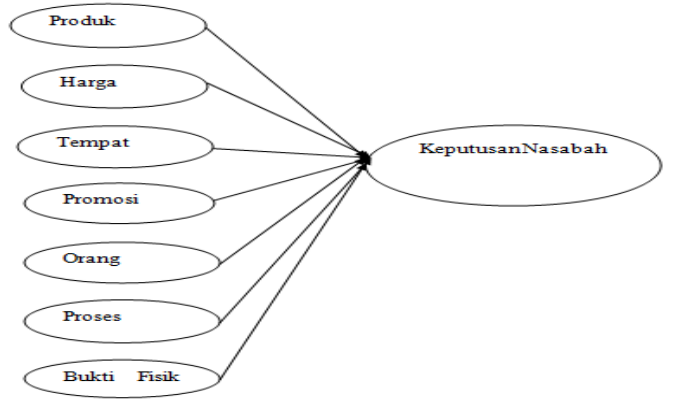

Gambar 1. Model Kerangka Pemikiran Berdasarkan latar belakang masalah dan permasalahan diatas serta model kerangka pemikiran maka hipotesis dalam penelitian ini adalah:

H1 : ada pengaruh produk terhadap keputusan nasabah untuk menabung pada Bank Mayapada Cabang A.Yani Pekanbaru.
H2 : ada pengaruh harga terhadap keputusan nasabah untuk menabung pada Bank Mayapada Cabang A.Yani Pekanbaru.

H3 : ada pengaruh lokasi terhadap keputusan nasabah untuk menabung pada Bank Mayapada Cabang A.Yani Pekanbaru.

H4 : ada pengaruh promosi terhadap keputusan nasabah untuk menabung pada Bank Mayapada Cabang A.Yani Pekanbaru.

H5 : ada pengaruh proses terhadap keputusan nasabah untuk menabung pada Bank Mayapada Cabang A.Yani Pekanbaru.

H6 : ada pengaruh orang terhadap keputusan nasabah untuk menabung pada Bank Mayapada Cabang A.Yani Pekanbaru.

H7 : ada pengaruh bukti fisik terhadap keputusan nasabah untuk menabung pada Bank Mayapada Cabang A.Yani Pekanbaru.

\section{METODE PENELITIAN}

Populasi yang digunakan dalam penelitian ini adalah seluruh nasabah Bank Mayapada International Tbk Cabang A.Yani Pekanbaru. Penarikan sampel dilakukan dengan menggunakan teknik accindental sampling dimana angket akan disebarkan pada nasabah yang berkunjung ke Bank Mayapada Cabang A.Yani. penentuan jumlah sampel penelitian dilakukan dengan menggunakan rumus Roscoe dengan jumlah sampel yang diteliti sebanyak 100 nasabah bank.

Data penelitian dilakukan dengan menggunakan data primer dan data sekunder yang bersumber dari angket, website perusahaan, literatur pustaka, jurnal maupun buku-buku yang mendukung penelitian. 
Tabel 2. Definisi Operasional Variabel

\begin{tabular}{|c|c|c|}
\hline Variabel & Definisi & Indikator \\
\hline $\begin{array}{l}\text { Produk } \\
\left(\mathrm{X}_{1}\right)\end{array}$ & $\begin{array}{l}\text { Produk } \\
\text { merupakan } \\
\text { sesuatu yang } \\
\text { ditawarkan untuk } \\
\text { menarik, } \\
\text { memuaskan, dan } \\
\text { memenuhi } \\
\text { keinginan dan } \\
\text { kebutuhan } \\
\text { konsumen. }\end{array}$ & $\begin{array}{l}\text {-Kemudahan } \\
\text { bertransaksi } \\
\text { menggunakan } \\
\text { menu mesin atm } \\
\text { Bank Mayapada } \\
\text {-Mempunyai fitur } \\
\text { ATM berupa } \\
\text { penarikan } \\
\text { uang,transfer, } \\
\text { pembelian dan } \\
\text { pembayaran yang } \\
\text { sesuai dengan } \\
\text { kebutuhan nasabah } \\
\text { - Produk yang } \\
\text { beragam }\end{array}$ \\
\hline $\begin{array}{l}\text { Harga } \\
\left(\mathbf{X}_{2}\right)\end{array}$ & $\begin{array}{lr}\text { harga } & \text { adalah } \\
\text { unsur penting } \\
\text { dimana dengan } \\
\text { adanya harga } \\
\text { maka perusahaan } \\
\text { akan } \\
\text { mendapatkan } \\
\text { pendapatan bagi } \\
\text { keberlangsungan } \\
\text { perusahaan } \\
\text { tersebut. }\end{array}$ & $\begin{array}{l}\text {-Biaya administrasi } \\
\text {-Suku Bunga } \\
\text { Tabungan } \\
\text { - Saldo minimum }\end{array}$ \\
\hline $\begin{array}{l}\text { Tempat } \\
\left(\mathbf{X}_{\mathbf{3}}\right)\end{array}$ & $\begin{array}{l}\text { Tempat (place) } \\
\text { merupakan } \\
\text { berbagai kegiatan } \\
\text { yang dilakukan } \\
\text { oleh perusahaan } \\
\text { untuk membuat } \\
\text { produknya mudah } \\
\text { diperoleh dan } \\
\text { tersedia pada } \\
\text { konsumen } \\
\text { sasaran. }\end{array}$ & $\begin{array}{l}\text {-Tempat parkir } \\
\text { yang memadai } \\
\text {-Lokasi yang } \\
\text { strategis dan mudah } \\
\text { dijangkau } \\
\text {-Suasana ruangan } \\
\text { bertransaksi yang } \\
\text { nyaman serta } \\
\text { terdapat fasilitas } \\
\text { yang memadai. }\end{array}$ \\
\hline $\begin{array}{l}\text { Promosi } \\
\left(\mathbf{X}_{4}\right)\end{array}$ & $\begin{array}{l}\text { Promosi adalah } \\
\text { kegiatan } \\
\text { mengkomunikasi } \\
\text { kan atau } \\
\text { menginformasika } \\
\text { n manfaat dari } \\
\text { sebuah produk } \\
\text { dan jasa pada } \\
\text { konsumen untuk } \\
\text { mendorong dan } \\
\text { membujuk } \\
\text { konsumen untuk } \\
\text { membeli atau jasa } \\
\text { tersebut. }\end{array}$ & $\begin{array}{l}\text {-Brosur } \\
\text { memberikan } \\
\text { informasi yang } \\
\text { lengkap } \\
\text { - Hadiah yang } \\
\text { menarik. } \\
\text {-Keramahan } \\
\text { customer service } \\
\text { dan teller } \\
\text { meningkatkan } \\
\text { loyalitas nasabah. }\end{array}$ \\
\hline & Proses & -Membuka \\
\hline
\end{tabular}

\begin{tabular}{|c|c|c|}
\hline $\begin{array}{l}\text { Proses } \\
\left(\mathbf{X}_{5}\right)\end{array}$ & $\begin{array}{l}\text { suatu upaya yang } \\
\text { dilakukan } \\
\text { perusahaan dalam } \\
\text { menjalankan dan } \\
\text { melaksanakan } \\
\text { aktivitasnya } \\
\text { untuk memenuhi } \\
\text { kebutuhan dan } \\
\text { keinginan } \\
\text { konsumen. }\end{array}$ & $\begin{array}{l}\text { tabungan dengan } \\
\text { cepat. } \\
\text {-keandalan dan } \\
\text { ketepatan } \\
\text {-menyelesaikan } \\
\text { keluhan nasabah } \\
\text { dengan baik dan } \\
\text { menyelesaikan } \\
\text { layanan tepat waktu }\end{array}$ \\
\hline $\begin{array}{l}\text { Orang } \\
\left(\mathbf{X}_{6}\right)\end{array}$ & $\begin{array}{lr}\text { Orang } & \text { adalah } \\
\text { pelaku } & \text { yang } \\
\text { terlibat langsung } \\
\text { dalam } \\
\text { menjalankan } \\
\text { aktivitas } \\
\text { perusahaan dan } \\
\text { merupakan faktor } \\
\text { yang memegang } \\
\text { peranan penting } \\
\text { bagi semua } \\
\text { organisasi. }\end{array}$ & $\begin{array}{l}\text {-memiliki } \\
\text { kemampuan dalam } \\
\text { memberikan } \\
\text { layanan secara } \\
\text { cepat } \\
\text {-memiliki } \\
\text { kemampuan yang } \\
\text { baik dalam } \\
\text { memberikan } \\
\text { penjelasan kepada } \\
\text { nasabah } \\
\text {-memberikan } \\
\text { pelayanan dengan } \\
\text { ramah }\end{array}$ \\
\hline $\begin{array}{l}\text { Bukti } \\
\text { Fisik } \\
\left(\mathbf{X}_{7}\right)\end{array}$ & $\begin{array}{lr}\text { Bukti fisik } & \text { merupakan suatu } \\
\text { hal yang } \\
\text { mempengaruhi } \\
\text { kepuasan } \\
\text { konsumen untuk } \\
\text { membeli dan } \\
\text { menggunakan } \\
\text { barang atau jasa } \\
\text { yang ditawarkan. }\end{array}$ & $\begin{array}{l}\text {-Ruang tunggu } \\
\text { yang nyaman } \\
\text {-Keamanan bank } \\
\text {-Penempatan papan } \\
\text { nama dan logo } \\
\text { bank yang jelas dan } \\
\text { mudah dikenali }\end{array}$ \\
\hline $\begin{array}{l}\text { Keputus } \\
\text { an } \\
\text { Nasabah } \\
\text { (Y) }\end{array}$ & $\begin{array}{l}\text { Keputusan } \\
\text { nasabah untuk } \\
\text { menabung } \\
\text { merupakan efek } \\
\text { akhir dari suatu } \\
\text { pembelian yang } \\
\text { diartikan sebagai } \\
\text { suatu sikap dan } \\
\text { niat untuk } \\
\text { berperilaku di } \\
\text { masa depan. }\end{array}$ & $\begin{array}{l}\text {-Keinginan } \\
\text { konsumen akan } \\
\text { produk tabungan di } \\
\text { Bank Mayapada } \\
\text {-Konsumen yakin } \\
\text { memilih Bank } \\
\text { Mayapada } \\
\text {-Konsumen akan } \\
\text { terus menggunakan } \\
\text { bank Mayapada dan } \\
\text { akan } \\
\text { merekomendasikan } \\
\text { nya kepada orang } \\
\text { lain }\end{array}$ \\
\hline
\end{tabular}

Sumber : Hasil Olahan Peneliti, 2017

Teknik Analisis Data

Persamaan regresi berganda dengan menggunakan 7 variabel independen dapat dinyatakan sebagai berikut : 
$\mathrm{Y}=\mathrm{a}+\mathrm{b}_{1} \mathrm{x}_{1}+\mathrm{b}_{2} \mathrm{x}_{2}+\mathrm{b}_{3} \mathrm{x}_{3}+\mathrm{b}_{4} \mathrm{X}_{4}+\mathrm{b}_{5} \mathrm{x}_{5}+\mathrm{b}_{6} \mathrm{x}_{6}$

$+\mathrm{b}_{7} \mathrm{x}_{7}+\mathrm{e}$

Di mana:

$\mathrm{Y}=$ Keputusan Nasabah Menabung

$\mathrm{a}=$ Konstanta

$\mathrm{X}=$ Variabel Independen (Produk, Harga, Lokasi, Promosi, Proses, Orang, Bukti Fisik)

$\mathrm{b}=$ Koefisien regresi untuk masing-masing variabel independen

e $=$ error

\section{Uji Pendahuluan}

Model regresi berganda yang digunakan harus memenuhi syarat uji pendahuluan terlebih dahulu untuk menilai kelayakan model penelitian yang akan digunakan. Uji ini meliputi uji validitas dan uji reliabilitas serta uji asumsi klasik yang mencakup uji multikolinieritas, uji autokorelasi, uji heterokedastisitas dan uji normalitas.

\section{Uji Model (Uji F)}

Uji model penelitian dilakukan untuk mengetahui apakah suatu model penelitian yang digunakan berpengaruh atau tidak terhadap hasil penelitian. Pengujian uji model dilakukan dengan menggunakan uji $\mathrm{F}$ dimana jika $F_{\text {hitung }}>F_{\text {tabel }}$ maka model penelitian yang digunakan berpengaruh dan layak untuk digunakan dalam penelitian ini. Sedangkan, jika $F_{\text {hitung }}<F_{\text {tabel }}$ model penelitian yang digunakan tidak berpengaruh dan belum layak untuk digunakan dalam penelitian ini

Uji Koefisien Determinasi $\left(\mathbf{R}^{\mathbf{2}}\right)$

Untuk melihat besarnya persentase sumbangan variabel independen terhadap variabel dependen secara keseluruhan. Nilai $\mathrm{R}^{2}$ berkisar pada angka 0 sampai 1 . Semakin besar $\mathrm{R}^{2}$ akan semakin baik bagi model regresi, karena variabel independen dapat menjelaskan variabel dependen secara lebih baik. Semakin besar $\mathrm{R}^{2}$ (mendekati 1) berarti semakin besar tingkat hubungan linear statistik dalam observasi.

\section{Uji Parsial (Uji t)}

Uji parsial (uji t) digunakan untuk mengetahui apakah variabel independen yang diteliti berpengaruh terhadap variabel dependen

Dasar analisis yang digunakan untuk penentuan besarnya tingkat pengaruh yakni:

1. Jika $t_{\text {hitung }}>t_{\text {tabel }}$ maka variabel independen berpengaruh terhadap variabel dependen.

2. Jika $t_{\text {hitung }}<t_{\text {tabel }}$ maka variabel independen tidak berpengaruh terhadap variabel dependen.

\section{HASIL DAN PEMBAHASAN}

Sebelum menghasilkan model regresi berganda, perlu dilakukan uji pendahuluan terlebih dahulu melalui uji validitas dan uji reliabilitas serta melakukan pengujian asumsi klasik.

Uji validitas data diperoleh dari hasil penyebaran angket terhadap 100 reponden dengan tingkat signifikansi sebesar 5\%. Tingkat validitas dilakukan dengan membandingkan nilai $\mathrm{r}$ hitung dan $\mathrm{r}$ tabel (0.195). jika nilai $r$ hitung $>r$ tabel maka angket penelitian dinyatakan valid.

Tabel 2. Hasil Uji Validitas

\begin{tabular}{|c|c|c|c|c|}
\hline Variabel & Item & $\begin{array}{l}\text { R } \\
\text { hitung }\end{array}$ & $R$ tabel & Keterangan \\
\hline \multirow[t]{3}{*}{ Produk } & Item 1 & 0.751 & \multirow[t]{3}{*}{0.195} & Valid \\
\hline & Item 2 & 0.731 & & Valid \\
\hline & Item 3 & 0.767 & & Valid \\
\hline \multirow[t]{3}{*}{ Harga } & Item 1 & 0.706 & \multirow[t]{3}{*}{0.195} & Valid \\
\hline & Item 2 & 0.797 & & Valid \\
\hline & Item 3 & 0.750 & & Valid \\
\hline \multirow[t]{3}{*}{ Lokasi } & Item 1 & 0.815 & \multirow[t]{3}{*}{0.195} & Valid \\
\hline & Item 2 & 0.849 & & Valid \\
\hline & Item 3 & 0.822 & & Valid \\
\hline \multirow[t]{3}{*}{ Promosi } & Item 1 & 0.743 & \multirow[t]{3}{*}{0.195} & Valid \\
\hline & Item 2 & 0.848 & & Valid \\
\hline & Item 3 & 0.804 & & Valid \\
\hline \multirow[t]{3}{*}{ Proses } & Item 1 & 0.698 & \multirow[t]{3}{*}{0.195} & Valid \\
\hline & Item 2 & 0.807 & & Valid \\
\hline & Item 3 & 0.711 & & Valid \\
\hline \multirow[t]{3}{*}{ Orang } & Item 1 & 0.684 & \multirow[t]{3}{*}{0.195} & Valid \\
\hline & Item 2 & 0.757 & & Valid \\
\hline & Item 3 & 0.708 & & Valid \\
\hline \multirow{3}{*}{$\begin{array}{l}\text { Bukti } \\
\text { Fisik }\end{array}$} & Item 1 & 0.791 & \multirow[t]{3}{*}{0.195} & Valid \\
\hline & Item 2 & 0.786 & & Valid \\
\hline & Item 3 & 0.736 & & Valid \\
\hline Keputusan & Item 1 & 0.690 & 0.195 & Valid \\
\hline
\end{tabular}




\begin{tabular}{|c|c|c|c|}
\hline \multirow[t]{3}{*}{ Nasabah } & Item 2 & 0.779 & Valid \\
\hline & Item 3 & 0.739 & Valid \\
\hline & Item 4 & 0.685 & Valid \\
\hline
\end{tabular}

Sumber: Hasil Olahan Peneliti, 2017

Uji reliabilitas berguna untuk melihat konsistensi hasil pengukuran bila dilakukan pengukuran kembali terhadap objek yang sama. Suatu angket dikatakan reliable atau handal jika nilai Cronbach Alpha $\geq 0,6$, maka variabel penelitian tersebut dikatakan reliable.

Tabel 3. Hasil Uji Reliabilitas

\begin{tabular}{lll}
\hline Variabel & Cronbach Alpha & Keterangan \\
\hline Produk & 0.802 & Reliabel \\
\hline Harga & 0.803 & Reliabel \\
\hline Lokasi & 0.838 & Reliabel \\
\hline Promosi & 0.826 & Reliabel \\
\hline Proses & 0.807 & Reliabel \\
\hline Orang & 0.783 & Reliabel \\
\hline Bukti Fisik & 0.813 & Reliabel \\
\hline $\begin{array}{l}\text { Keputusan } \\
\text { Nasabah }\end{array}$ & 0.788 & Reliabel \\
\hline Sumb & & \\
\hline
\end{tabular}

Sumber: Hasil Olahan Peneliti, 2017

Uji asumsi klasik terdiri dari uji multikolineartitas, uji autokorelasi, uji heteroskedastisitas dan uji normalitas. Berdasarkan uji asumsi klasik diperoleh hasil baha data terdistribusi normal serta tidak memiliki gejala multikolinearitas, autokorelasi dan heteroskedastisitas.

\section{Hasil Uji Model (Uji F)}

Uji model digunakan untuk mengetahui apakah suatu model penelitian yang digunakan berpengaruh atau tidak terhadap hasil penelitian.

Tabel 4. Hasil Uji F

\begin{tabular}{llll}
\hline Model & Df & F-Hitung & Sig \\
\hline Regression & 7 & 6.442 & 0.000 \\
\cline { 1 - 2 } Residual & 92 & & \\
\cline { 1 - 2 } Total & 99 & & \\
\hline
\end{tabular}

Sumber: Hasil Olahan Peneliti, 2017

Berdasarkan tabel 4 diatas diperoleh F Hitung lebih besar dari F Tabel $(6,442>$ 2,11) dan nilai signifikansi $0,000<0,05$. Maka hal ini menunjukkan bahwa variabel independen yaitu produk, harga, tempat, promosi, proses, orang, dan bukti fisik secara bersama-sama berpengaruh terhadap keputusan nasabah yang menabung pada PT.
Bank Mayapada Internasional, Tbk cabang A.Yani Pekanbaru. Dengan demikian dapat disimpulkan bahwa model penelitian yang digunakan sudah bagus.

\section{Hasil Uji Koefisien Determinasi $\left(\mathbf{R}^{2}\right)$}

Koefisien determinasi bertujuan menunjukan besarnya derajat hubungan antara produk, harga, lokasi, promosi, proses, orang, dan bukti fisik terhadap keputusan nasabah.

Tabel 5. Hasil Uji $\mathbf{R}^{2}$

\begin{tabular}{llll}
\hline Model & $\mathbf{R}$ & R-Squared & Adj. R Square \\
\hline 1 & 0.574 & 0.329 & 0.278 \\
\hline $\begin{array}{c}\text { Sumber: Hasil Olahan Peneliti, } 2017 \\
\text { Dari hasil pengujian yang telah }\end{array}$
\end{tabular}
dilakukan dapat dilihat dari nilai Ajusted $\mathrm{R}^{2}$ sebesar 0.278 dapat diartikan bahwa variabel independen yaitu produk, harga, lokasi, promosi, proses, orang, dan bukti fisik mempunyai pengaruh terhadap keputusan nasabah sebesar $27,8 \%$, sedangkan sisanya sebesar $72.2 \%$ dipengaruhi oleh variabel lain yang tidak diamati dalam penelitian ini seperti citra merek, pelayanan, dan kepercayaan pada bank.

Estimasi model regresi liner berganda ini menggunakan software SPSS 19 dan diperoleh hasil output sebagai berikut:

$\mathrm{Y}=1,112+0,268 X 1-0,002 X 2+0,244 X 3+$ 0,147X4 - 0,218X5 + 0,246X6+ 0,049X7

Hasil Uji Parsial (uji t)

Uji parsial (uji t) digunakan untuk mengetahui apakah variabel independen yang diteliti berpengaruh terhadap variabel dependen. Dari hasil tabel analisis regresi di atas dapat dilihat bahwa tidak semua variabel independen yang digunakan dalam model penelitian mempunyai t-hitung dan tingkat signifikansi $<0,05$.

\section{Tabel 6. Hasil Uji t}

\begin{tabular}{|c|c|c|c|}
\hline Variabel & T hitung & T Tabel & Sig \\
\hline Produk & 2.813 & \multirow[t]{6}{*}{1.986} & 0.006 \\
\hline Harga & -0.019 & & 0.985 \\
\hline Lokasi & 2.988 & & 0.004 \\
\hline Promosi & 1.625 & & 0.108 \\
\hline Proses & -2.122 & & 0.037 \\
\hline Orang & 2.375 & & 0.020 \\
\hline
\end{tabular}




\begin{abstract}
Bukti Fisik 0.507
Sumber: Hasil Olahan Peneliti, 2017

Berdasarkan hasil pengolahan dengan SPSS, variabel produk, lokasi, dan orang berpengaruh positif dan signifikan terhadap keputusan nasabah menabung, variabel proses berpengaruh negatif dan signifikan terhadap keputusan nasabah menabung sedangkan variabel harga, promosi dan bukti fisik tidak berpengaruh signifikan terhadap keputusan nasabah menabung keputusan nasabah menabung.
\end{abstract}

\section{Pengaruh Produk Terhadap Keputusan Nasabah}

Variabel produk berpengaruh positif dan signifikan terhadap keputusan nasabah. Hal ini sesuai dengan hasil penelitian terdahulu yang dilakukan oleh Purwati (2015) yang menyatakan bahwa variabel produk berpengaruh positif dan signifikan terhadap keputusan menabung. Akan tetapi tidak sesuai dengan penelitian yang dilakukan oleh Kurnianto (2013) yang menyatakan bahwa variabel produk tidak berpengaruh dan tidak signifikan terhadap keputusan konsumen yang menabung.

Hal ini disebabkan karena nasabah terpengaruh terhadap variabel produk seperti produk tabungan yang dilengkapi dengan fasilitas ATM yang mempunyai fitur berupa penarikan uang, transfer, pembelian dan pembayaran yang sesuai dengan kebutuhan nasabah serta memiliki jenis-jenis tabungan yang bervariasi sesuai dengan kebutuhan nasabah. Akan tetapi variabel produk masih kurang bervariasi dan kurang menarik sehingga terjadinya penurunan jumlah nasabah. Hal ini merupakan salah satu hal yang perlu diperhatikan oleh bank untuk dapat meningkatkan variabel produk sehingga produk yang ditawarkan dapat memenuhi kebutuhan dan keinginan nasabah serta mendorong nasabah melakukan keputusan menabung.

\section{Pengaruh Harga Terhadap Keputusan Nasabah}

Variabel harga tidak berpengaruh signifikan terhadap keputusan nasabah. Hal ini sesuai dengan hasil penelitian terdahulu yang dilakukan oleh Gusnawati (2014) yang menyatakan bahwa variabel harga tidak berpengaruh signifikan terhadap keputusan nasabah untuk menabung. Akan tetapi tidak sesuai dengan penelitian yang dilakukan oleh Kurnianto (2013) yang menyatakan bahwa variabel harga berpengaruh negatif dan signifikan terhadap keputusan konsumen yang menabung.

Hal ini disebabkan karena nasabah tidak terpengaruh terhadap variabel harga seperti biaya administrasi, tingkat suku bunga, dan saldo minimum dalam memutuskan keputusan menabung yang dikarenakan nasabah lebih memperhatikan produk yang sesuai dengan kebutuhan dan keinginannya serta orang atau karyawan yang bekerja di bank dapat memberikan kepuasan atau kenyamanan terhadap nasabah sehingga nasabah memutuskan untuk menabung. Nasabah menganggap biaya yang dikeluarkan untuk menabung pada PT. Bank Mayapada Internasional, Tbk cabang A.Yani Pekanbaru sama seperti menabung pada bank yang lain.

\section{Pengaruh Lokasi Terhadap Keputusan} Nasabah

Variabel lokasi berpengaruh positif dan signifikan terhadap keputusan nasabah. Hal ini sesuai dengan hasil penelitian yang dilakukan oleh Yulianto (2010) yang menyatakan bahwa lokasi berpengaruh positif dan signifikan keputusan nasabah. Akan tetapi tidak sesuai dengan penelitian yang dilakukan oleh Sari (2015) yang menyatakan bahwa variabel lokasi tidak berpengaruh signifikan terhadap keputusan nasabah yang menabung.

Hal ini dikarenakan bank memiliki lokasi yang strategis sehingga nasabah dapat lebih mudah menjangkau lokasi dalam 
bertransaksi, tempat parkir yang memadai, dan suasana ruangan bertransaksi yang nyaman serta terdapat fasilitas yang memadai. Akan tetapi bank masih memiliki tempat parkir yang sempit sehingga nasabah susah untuk memarkirkan kendaraannya sehingga dapat menjadi penyebab penurunan jumlah nasabah.Semakin strategis variabel tempat yang diberikan oleh bank, maka keputusan nasabah juga akan semakin tinggi.

Pengaruh Promosi Terhadap Keputusan Nasabah

Variabel promosi tidak berpengaruh signifikan terhadap keputusan nasabah. Hal ini sesuai dengan hasil penelitian terdahulu yang dilakukan oleh Kurnianto (2013) yang menyatakan bahwa variabel promosi tidak berpengaruh dan tidak signifikan terhadap keputusan konsumen yang menabung. Akan tetapi tidak sesuai dengan penelitian yang dilakukan Sari (2015) yang menyatakan bahwa variabel promosi berpengaruh positif dan signifikan terhadap keputusan nasabah yang menabung.

Hal ini disebabkan karena kegiatan promosi yang dilakukan oleh bank sama seperti bank-bank lainnya sehingga tidak mempunyai pengaruh ayng signifikan terhadap pengambilan keputusan menabung. Saat ini bank lebih memfokuskan promosi melalui marketing dibandingkan dengan promosi melalui brosur, iklan, dan lain sebagainya sehingga hal ini menjadi perhatian yang serius bagi bank untuk meningkatkan usaha promosinya agar market share dapat dicapai sesuai dengan target perusahaan.

\section{Pengaruh Proses Terhadap Keputusan Nasabah}

Variabel proses berpengaruh negatif signifikan terhadap keputusan nasabah. Hal ini tidak sesuai dengan hasil penelitian terdahulu yang dilakukan oleh Arifin (2013) yang menyatakan bahwa variabel proses berpengaruh positif dan signifikan terhadap keputusan menabung. namun tidak sesuai dengan penelitian yang dilakukan Gusnawati (2014) yang menyatakan bahwa variabel proses tidak berpengaruh dan tidak signifikan terhadap keputusan nasabah.

Hal ini dikarenakan bank telah menetapkan bahwa salah satu syarat pembukaan tabungan bagi nasabah adalah memiliki NPWP. Nasabah harus menyatakan lembar persetujuan bahwa data nasabah akan diperlihatkan kepada pajak. Di Indonesia masih banyak nasabah yang menghindar dari pembayaran pajak. Hal inilah yang dapat menyebabkan proses berpengaruh negatif signifikan terhadap keputusan nasabah.

Pengaruh Orang Terhadap Keputusan Nasabah

Variabel orang berpengaruh positif dan signifikan terhadap keputusan nasabah. Hal ini sesuai dengan hasil penelitian terdahulu yang dilakukan oleh Gusnawati (2014) yang menyatakan bahwa variabel orang berpengaruh positif dan signifikan terhadap keputusan nasabah. Akan tetapi tidak sesuai dengan penelitian yang dilakukan oleh Yulianto (2010) yang menyatakan bahwa variabel orang tidak berpengaruh dan tidak signifikan terhadap pertimbangan nasabah.

Hal ini dikarenakan kemampuan karyawan dalam memberikan layanan secara tanggap dan mampu memberikan penjelasan kepada nasabah, menyapa nasabah dengan memberikan senyum dan salam. Akan tetapi variabel orang pada bank masih perlu ditingkatkan khususnya dalam hal pelayanan karyawan dalam memberikan service excellent kepada nasabah.

\section{Pengaruh Bukti Fisik Terhadap Keputusan Nasabah \\ Variabel bukti fisik tidak} berpengaruh signifikan terhadap keputusan nasabah. Hal ini sesuai dengan hasil penelitian terdahulu yang dilakukan oleh Arifin (2013) yang menyatakan bahwa 
variabel bukti fisik tidak berpengaruh dan tidak signifikan terhadap keputusan nasabah. Akan tetapi tidak sesuai dengan penelitian yang dilakukan oleh Kurnianto (2013) yang menyatakan bahwa variabel bukti fisik berpengaruh positif dan signifikan terhadap keputusan konsumen yang menabung.

Hal ini dikarenakan fitur-fitur transaksi yang disediakan antara 1 bank dengan bank lainya serupa dan tidak memiliki perbedaan yang signifikan seperti firut penarikan tunai, pengecekan saldo, pencetakan buku tabungan dan sebagainya. Sistem perbankan pun memiliki kemiripan satu sama lain dikarenakan perbankan mengikuti standar yang ditetapkan oleh Bank Indonesia.

\section{PENUTUP}

\section{Kesimpulan}

Berdasarkan hasil analisis dan pembahasan dapat ditarik kesimpulan bahwa produk, lokasi, dan orang berpengaruh positif dan signifikan terhadap keputusan nasabah menabung, variabel proses berpengaruh negatif dan signifikan terhadap keputusan nasabah menabung sedangkan variabel harga, promosi dan bukti fisik tidak berpengaruh signifikan terhadap keputusan nasabah menabung keputusan nasabah menabung.

Saran

Adapun saran yang dapat diberikan dalam penelitian ini adalah pertama, bagi perusahaan yakni menetapkan strategi pemasaran yang tepat dan sesuai dengan kebutuhan dan keinginan nasabah serta memperhatikan keluhan-keluhan nasabah selama melakukan transaksi dibank. Kedua, bagi peneliti selanjutnya diharapkan dapat lebih memperhatikan seluruh variabel independen yang digunakan karena dalam penelitian ini terdapat beberapa perbedaan hasil dengan penelitian terdahulu, memperluas ruang lingkup penelitian dan jumlah sampel penelitian yang digunakan serta memperpanjang periode penelitian, menambah variabel independen dan memperbaharui variabel dependen sehingga akan memberi gambaran hasil yang lebih mendekati kondisi sebenarnya

\section{DAFTAR PUSTAKA}

Arifin, Zainul Wilopo. (2013). Pengaruh Bauran Pemasaran Jasa Terhadap Keputusan Konsumen Memiliki Kartu Kredit BRI (Studi Kasus Pada BRI Kantor Cabang Solo Slamat Riyadi ). Jurnal Administrasi Bisnis. Malang.

Gusnawati, Reni. (2014). Pengaruh Marketing Mix Terhadap Keputusan Nasabah Untuk Menabung Simpedes di PT. Bank Rakyat Indonesia (PERSERO) Tbk Unit Batang Kapas Cabang Painan. Jurnal Pendidikan Ekonomi. Painan.

Hasan, Ali. (2013). Marketing dan KasusKasus Pilihan. CAPS (Center For Academic Publishing Service). Yogyakarta

Hurriyati, Ratih. (2010). Bauran Pemasaran dan Loyalitas Konsumen. Alfabeta. Bandung.

Kotler, Philip and Gary Armstrong. (2012). Prinsip-Prinsip Pemasaran 2. Edisi 13. Jilid 1. Erlangga. Jakarta.

Kotler, Philip and Kevin Lane Keller. (2016). Manajemen Pemasaran, Jilid 1 dan 2.

Kurniato, Ernan. (2013). Pengaruh Marketing Mix Terhadap Keputusan Costumer Menabung di Taheta PT. Bank Pembangunan Daerah Kalimantan Tengah Cabang Tamiang Layang. Jurnal Pendidikan Ekonomi. Tamiang Layang. 
Lovelock, and Jochen Wirtz. (2011). Service Marketing People, Technology, Strategy. 7th edition. Upper Saddle River, New Jersey: Pearson Hall.

OJK. www.ojk.go.id (diakses pada September 2017)

Sari, Devi Kumala. (2015). Faktor-faktor Bauran Pemasaran Jasa yang mempengaruhi Keputusan Nasabah Menabung Tabungan Prama di Bankalti Cabang Utama Samarinda. Jurnal Administrasi Bisnis. Samarinda.

Tjiptono, Fandy. (2011). Pemasaran Jasa. Bayumedia. Malang

Purwati, A,A. (2015). Analisis Harapan dan Kepuasan Mahasiswa Indonesia
Terhadap Strategi Marketing Mix (7p) Di Universiti Kebangsaan Malaysia (UKM) dan Universiti Malaya (UM). PROCURATIO (Jurnal Ilmiah Manajemen), Vol 3 No 2. Hal. 111-122.

Yulianto, Firman. (2010). Analisis Pengaruh faktor Bauran Pemasaran Terhadap Pertimbangan Nasabah Dalam Memilih Bank Syariah Di Kota Medan. Jurnal Administrasi Bisnis. Medan. 